\title{
Dějiny tvoři "ti malí" aneb Život a dílo Emanuela Ambrose
}

\section{The History is Created by "the little ones": The Life and Work of Emanuel Ambros}

Milan Balódy / MilanBalody@seznam.cz

Department of Musicology, Faculty of Arts, Palacký University, Olomouc, CZ

\begin{abstract}
The study maps the life and creative legacy of Emanuel Ambrose (1885-1955), who significantly influenced the cultural development in Moravia. From the position of secondary school teacher, popular-educational worker and music critic he educated the widest social classes of population during the era which absented some of today's inherent mass media. Ambrose's organizational ambitions found application in Olomouc and Brno where, in addition to cooperation with local associations, he initiated the establishment of new corporations, or organized valuable concert productions.
\end{abstract}

\section{Keywords}

Emanuel Ambros, 1885-1955, Olomouc, Brno, music education, music association

Příspěvek vznikl za podpory MŠMT, grant IGA_FF_2018_010: Hranice popularity v hudbě 19. až 21. století a grant IGA_FF_2019_006. 


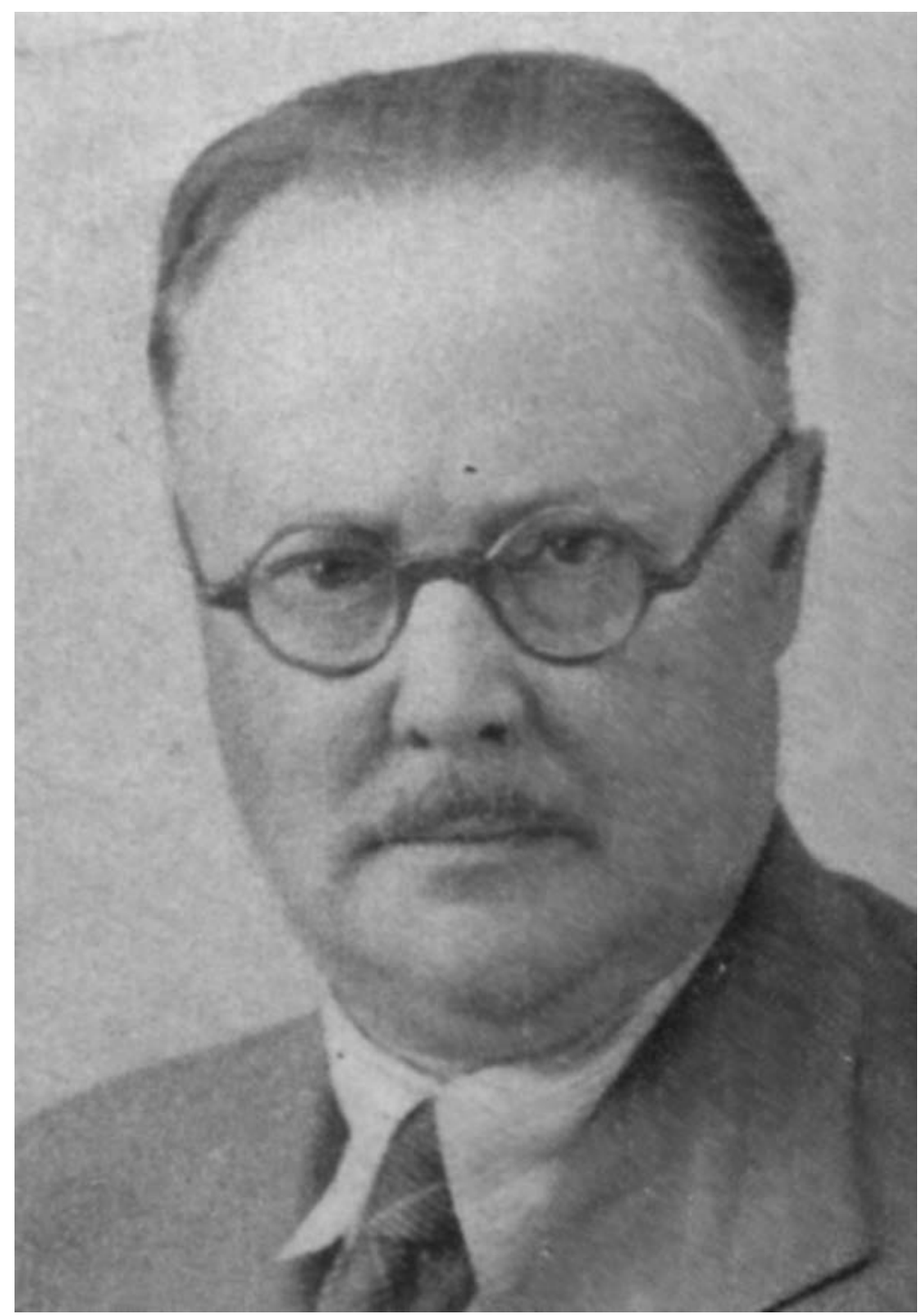

Obr. 1 Emanuel Ambros - portrétní fotografie užívaná v korespondenci a literatuře v průběhu čtyřicátých let 20. století. Zdroj: Dvacet let českého divadla v Olomouci. Olomouc, [1941], s. 15.

Předkládaný text reflektuje životní osudy a tvůrčí odkaz pedagoga a hudebníka Emanuela Ambrose (1885-1955), který podnětně zasáhl do kulturního dění na Moravě. Zvláště v prvorepublikové Olomouci a později také v Brně spoluprací s místními organizacemi nebo vlastní iniciativou participoval na zkvalitnění uměleckého života. Po vzoru Bohumíra Štědroně konstatujme, že Emanuel Ambros představoval novodobého „kantora“, důležitého podílníka v dějinném vývoji české hudebnosti. 


\section{Dětství a studium}

Emanuel Ambros se narodil v Kroměříži dne 26. září 1885 rodičům Ezechielovi a Marii Ambrosovým, kteří svého prvorozeného syna nechali pokřtít ve zdejším farním kostele Nanebevzetí Panny Marie na Emanuela Františka Jana Ezechiela Mariu. ${ }^{1}$ Od září roku 1888 přijal absolvent brněnského učitelského ústavu a pražské varhanické školy Ezechiel Ambros (1861-1915) místo ředitele kưru farního kostela Povýšení sv. Kříže v Prostějově, kam rodina natrvalo přesídlila. Kromě funkce regenschoriho pedagogicky působil na prostějovském reálné škole a později gymnáziu, založil hudební školu a stal se sbormistrem zdejších pěveckých spolků Orlice a Vlastimila. Hudební rozvoj svých čtyřech synů podporovala i Emanuelova matka Marie Ambrosová, rozená Zapletalová (18651911). ${ }^{2}$ Vliv výchovy a inspirativního uměleckého zázemí rodiny nejlépe deklaruje př́́klad Emanuelova bratra Vladimíra Ambrose (1890-1956), jenž se stal významným českým skladatelem první poloviny 20. století. $^{3}$

Po středoškolských studiích v Prostějově a Jevíčku se devatenáctiletý Emanuel Ambros přihlásil na Českou vysokou školu technickou v Praze. Poté se v letech 1906 až 1908 vzdělával na filozofické fakultě Karlo-Ferdinandovy univerzity. Naskytla se mu tak možnost doslova pod jednou střechou pražského Klementina kromě povinných lekcí matematiky a fyziky navštěvovat přednášky Otakara Hostinského a Zdeňka Nejedlého. Kromě toho se stal soukromým žákem Vítězslava Nováka a Adolfa Piskáčka. ${ }^{4}$ Posledně jmenovaný podle dochované vzpomínky ${ }^{5}$ Ambrose motivoval k absolvování státní zkoušky ze zpěvu pro střední školy a učitelské ústavy, kterou úspěšně složil dne 28. dubna 1908 na Pražské konzervatoři. ${ }^{6}$ Pedagogickou způsobilost pro výuku středoškolské matematiky, geometrie a fyziky získal teprve v květnu $1920 .^{7}$

1 Moravský zemský archiv Brno, matrika narozených v Kroměříži, inv. č. 7951, s. 279.

2 Podrobně viz SILNÁ, Ingrid. Ezechiel Ambros. Olomouc: Univerzita Palackého v Olomouci, 2011.

3 Český skladatel a dirigent Vladimír Ambros se narodil dne 18. záři 1890 v Prostějově. Po absolvování brněnské varhanické školy odešel do Frankfurtu nad Mohanem, kde studoval na konzervatoři a přijal místo korepetitora opery. V letech 1914-1921 byl kapelníkem londýnské operní scény Carl-Rossa \& Co. Následně se vrátil do Československa, kde působil v Prostějově a Břeclavi. Zemřel 12. května 1956 v Prostějově. Skladatelský odkaz Vladimíra Ambrose zahrnuje více než 130 opusů, z nichž jmenujme alespoň opery Ukradené štěstí a Maryla, z orchestrální tvorby pak 3 symfonie, symfonickou báseň Balada o nenarozeném dítéti a trilogii Beskydy. Podrobněji viz GREGOR, Vladimír. Vladimír Ambros. Prostějov: Okresní vlastivědné muzeum, 1969.

4 ŠTĚDROŇ, Bohumír. Ambros Emanuel. In Československý hudebni slovnik osob a instituci. Černušák, Gracian - Štědroň, Bohumír - Nováček, Zdenko (eds.). Svazek první. Praha: Státní hudební vydavatelství, 1963 , s. 25-26.

5 AMBROS, Emanuel. Ředitel Josef Klvaňa a hudba. In Čtyřicet let československého státního reálného gymnasia Josefa Klvani v Kyjově 1898-1938. Kolaja, Maxmilián (ed.). Kyjov, 1938, s. 175.

6 Archiv hlavního města Prahy, matrika c. k. zkušební komise pro učitele hudby na školách středních a ústavech učitelských v Praze, č. 552/1908, Emanuel Ambros.

7 Viz STROUHAL, Vincenc. Zkoušky pro učitelství na školách středních, dívčích lyceích a na školách obchodních v letním období 1920. Věstnik českých profesorů (část stavovská), roč. XXVII, č. 16-17, 3. 6. 1920, s. 362-364. 


\section{Pedagogická činnost}

Pobyt v Praze Emanuel Ambros přerušil kvůli působení na učitelském ústavu v Polské Ostravě, kde celý školní rok 1908/1909 suploval za neurastenií postiženého Rudolfa Wünsche (1880-1955). Jeho devatenáctihodinový úvazek zahrnoval výuku nauky o hudbě a zpěvu dohromady, hry na housle a na klavír. ${ }^{8}$ Úspěšně navázal na tradici pořádání veřejných produkcí ústavu, když na program historicky třetí studentské akademie konané dne 16. května 1909 zařadil obtížné mužské sbory Oráč Josefa Bohuslava Foerstera, Drahé vlasti Bohuslava Jeremiáše a Piseň Velkého pátku Otakara Nebušky. ${ }^{9}$ Mimo zaměstnání se Emanuel Ambros stýkal v Ostravě s významnými osobnostmi regionu, z nich jmenujme alespoň Eduarda Bartoníčka (1855-1915), Cyrila Metoděje Hrazdiru (1868-1926) či Leoše Janáčka (1854-1928). ${ }^{10}$

Z dalších přechodných působišt Emanuela Ambrose uved'me Vyšší reálné gymnázium v jihomoravském Kyjově, kde vyučoval v letech 1910-1913. Poté se krátce vrátil do Prahy, aby zde přijal místo na I. české státní reálné škole na Královských Vinohradech. Po vypuknutí válečného konfliktu nastoupil jako suplující učitel na Zemské vyšší reálné škole a státním gymnáziu v Prostějově, kde nahradil svého nemocného otce, který 31. května 1915 zemřel. Rodinné neštěstí umocnil v červnu toho roku povolávací rozkaz na vojnu. Nucené nasazení v 1. světové válce a období těsně po jejím skončení, kdy se Emanuel Ambros oženil s Annou Marií Novosadovou (1897-?), zůstává jedním z nejuceleněji zaznamenaných období jeho života, nebot si po otcově vzoru vedl osobní deník. ${ }^{11}$ Po válce se se svým tchánem pokusil podnikat v Nákupním a prodejním družstvu moravských řezníků a uzenářů v Brně. ${ }^{12}$ V moravské metropoli ve školním roce 1919/1920 působil na Dvoutřídní dívčí obchodní škole a šestiletém Dívčím lyceu. ${ }^{13}$

Období fluktuace ukončilo absolvování výše zmíněných státních zkoušek a přesídlení do Olomouce, kde Ambros po jednoročním setrvání na České státní reálce od roku 1921 dalších čtrnáct let působil jako profesor matematiky, fyziky, němčiny a nepovinného zpěvu na Státním dívčím reformním reálném gymnáziu. ${ }^{14}$ Chceme-li pochopit původ rozsahu Ambrosovy agitační práce v kulturně pomalu se vzmáhající, dříve značně germanizované Olomouci, nutně musíme kořeny jeho aktivit hledat právě na dívčím reálném gymnáziu. Škola, vedená agilním Klementem Králíkem (1881-1954), ${ }^{15}$ všemožně

8 Školní zprávy. Sbor učitelský ve šk. roce 1908/9. In Prvni zpráva c. k. ústavu na vzděláváni učitelů v Polské Ostravě za dobu od šk. roku 1905-06 do šk. roku 1908-09. Slezská Ostrava, 1909, s. 61.

9 K. B. Hudební a pěvecká akademie. Ostravské listy, roč. IV, č. 61, 24. 5. 1909, s. 1.

10 Podle připojených vlastnoručních podpisů na pozdravné dopisnici otci ze dne 2. ř́jna 1908. Viz Muzeum Prostějovska v Prostějově, Památník Ezechiela Ambrosa II. (1905-1915), inv. č. 110.

11 Státní okresní archiv (dále SOkA) Prostějov, fond Emanuel Ambros, Rodinná kronika 1914-1919, 20 stran.

12 Zapsání do rejstř́íků společenstev. Brněnské noviny (př́loha) 23. května 1919, č. 118, s. 1.

13 SOkA Prostějov, fond Emanuel Ambros, Rodinná kronika 1914-1919, s. 19.

14 SOkA Olomouc, fond M5-30: Státní dívčí reálné gymnázium Olomouc, kronika, inv. č. 75.

15 Kelčský rodák Klement Králík se narodil 5. listopadu 1881. Po vysokoškolských studiích v Praze a Jeně učil v Mladé Boleslavi a Telči. Do Olomouce přesídlil roku 1911, kdy přijal místo na České státní reálce. Ředitelem 
podporovala rozvoj „českojazyčné“ části města - počínaje propůjčováním učebních místností jiným institucím, přes lidovýchovné, publikační a organizační aktivity jednotlivých pedagogů až po pořádání vlastních kulturních podniků.

Veřejné koncerty, jako jedny z výrazných reprezentačních artiklů dívčího ústavu, našly v Ambrosově osobě vytrvalého iniciátora. Pozitiva podobných akcí spatřoval zejména v motivaci (sdílení určitého cíle), praktickém uplatnění nácviku a v možnosti vytrhnout žáky ze všednosti školních povinností. ${ }^{16}$ Přibývající počet studujících gymnazistek, nárůst obliby výuky zpěvu a s tím spojená konsolidace sboru umožnily při akademiích interpretovat obtížnější skladby předních autorů. Vedle vokálních sborových kompozic a sólových výstupů doplňovala program různá instrumentální čísla, recitace básní, proslovy a pohybová (rytmická) cvičení. Zhruba od poloviny dvacátých let Ambros dramaturgii některých vystoupení tematicky sjednocoval. To znamenalo u př́ležitosti výročí významných skladatelů pořádat koncerty, na nichž primárně zaznívala jubilantova díla, zpravidla ještě doplněna přednáškou o životě a tvorbě autora. ${ }^{17}$ Atraktivitu zároveň zvyšovalo spoluúčinkování profesionálních umělců (Vladimír Ambros, Marie Hloušková, Ludvík Kundera, Libuše Svobodová aj.), kteří některé skladby interpretovali dokonce v olomouckých premiérách. ${ }^{18}$ Každý koncert byl pro svou nadstandartní úroveň přesahující atributy školního muzicírování provázen velice pozitivním hodnocením v lokálním tisku. Jedním z mála odpůrců Ambrosovy osoby a činnosti v Olomouci se stal pedagog, sbormistr a hudební kritik František Waic (1866-1939), v jehož pozůstalosti nalézáme mnoho zpráv negativně reflektujících Ambrosovo bytí. ${ }^{19} \mathrm{~V}$ konkrétním případě akademií

dívčího gymnázia (t. č. Českého dívčího lycea) se stal v druhém roce existence ústavu (1920). V Olomouci platil za činorodého pracovníka angažovaného např. v Městském osvětovém sboru, Městské knihovní radě, Národní jednotě, kulturní rubrice periodika Pozor, Krajském odboru Ústředního spolku československých profesorů, Dobrovského vyšší lidové škole, Klubu přátel umění aj. Viz FISCHER, Richard. Klement Králík. In Fischer, Richard (ed.). Olomoucký památnik 1848-1918. Olomouc, 1938, s. 158-159.

Králíkovu pozůstalost spravuje SOkA Olomouc, fond M8-50: Klement Králík.

16 AMBROS, Emanuel. Středoškolské akademie (koncerty). Hudební rozhledy, roč. III, č. 9-10, s. 167-168.

17 Dne 9. dubna 1927 dívčí reálné gymnázium uspořádalo interní oslavu stého výročí úmrtí Ludwiga van Beethovena, při níž umělecký profil skladatele přiblížil hudební vědec Jan Racek (1905-1979). Došlo tak k navázání přátelského kontaktu mezi Emanuelem Ambrosem a Janem Rackem, kterou dokládá vzájemná korespondence uložená v Moravském zemském muzeu, Oddělení dějin hudby (dále jen MZM ODH), sign. G 980.

18 Vycizelovat produkci věnovanou tvorbě konkrétního autora jeho návštěvou se Ambrosovi bohužel nepodařilo, i když nalézáme důkazy snah takováto přizvání realizovat. Např. při Foersterově oslavě dne 27 . března 1927 (návštěvu Olomouce Foersterovi znemožnila vážná nemoc - viz MZM ODH: Korespondence Jana Racka s Emanuelem Ambrosem, dopis z 16. března 1927, sign. G 980, inv. č. 72. 885) nebo večeru Vítězslava Nováka dne 20. dubna 1929 (viz Dr. J. R. Večer Vítězslava Nováka. Ústřižek článku v neoznačených novinách uložený ve Vlastivědném muzeu v Olomouci, fond František Waic, karton 14).

19 Vzájemnou nesnášenlivost patrně zapř́ičinila osobní rozepře vyvolaná v souvislosti s kauzou v Pěveckém sdružení moravských učitelů na zasedání v Luhačovicích roku 1921. V době vážné nemoci zakladatele a dirigenta sdružení Ferdinanda Vacha (1860-1939) se všeobecně spekulovalo o dalších osudech spolku. František Waic zneužil obsah privátní konverzace s Emanuelem Ambrosem a před plénem odsoudil domnělou snahu Ambrosova přítele Viléma Steinmana (1880-1962) nahradit Vachovo místo (viz MZM ODH: Ambrosův dopis Vilému Steinmanovi z 27. července 1921, sign. G 259). Výsledkem celé události byla žádost podepsaná více jak dvaceti členy sdružení o rezignaci Františka Waice z funkce předsedy. Událost zapříčinila odchod Viléma Steinmana z PSMU (viz Vlastivědné muzeum v Olomouci, fond František Waic, karton 26). 
Františku Waicovi vadila např. hlasová nevyspělost studentů a mimoumělecké záměry podobných slavností souvisejících s propagací a obohacováním pořádajícího ústavu. ${ }^{20}$

Ambrosovo působení při jeho odchodu z dívčího gymnázia zhodnotilo rodičovské sdružení školy následovně: „Bylt’ znám suým spravedlivým oceňováním schopnosti a pilnosti sobě svěrené mládeže a znali ho všichni z produkcí a koncertů, jež se svými žačkami pořádal. [...]. Jeho obětavé a neumdlévajici činnosti při nacvičováni divčich sborü, spoluprisobeni při všech školnich slavnostech, jeho otcovské působeni při vyučováni nebude zapomenuto. A jeho milý způsob jednáni $k$ tomu mu ziskaly mnoho tichých a oddaných prátel, již lituji jeho odchodu [...]. "21

$\mathrm{S}$ přáním horlivějšího hudebně-kritického a pedagogického uplatnění byl Emanuel Ambros na vlastní žádost přeložen od 1. září 1935 na Státní československé reformní gymnázium v Brně-Králově Poli, odkud po třech školních letech odešel do služeb Pátého státního reálného gymnázia v Brně-Žabovřeskách. Poprvé byl nedobrovolně penzionován v létě 1941. O reaktivaci do služeb gymnázia se přihlásil na začátku května $1945 .{ }^{22}$

V poválečném období Emanuel Ambros na základě osobní intervence vůdčích představitelů ministerstva školství a dalších hudebních pedagogů shromážděných na celonárodním sjezdu v Litomyšli (29.-30. srpna 1945) 23 $^{23}$ aspiroval na pozici inspektora hudební výchovy. Do této funkce nakonec ministr školství Zdeněk Nejedlý jmenoval mladšího Jaromíra Michala (1900-1959). Vzniklá situace vedla Ambrose k demonstrativnímu vzdání se hudebních aktivit zaštitovaných státní sférou, včetně výuky zpěvu a hudební výchovy. ${ }^{24}$ Až do 30. září 1949, kdy byl s konečnou platností přeložen do penze ${ }^{25}$, vyučoval na gymnáziu matematické předměty a od hudební výchovy se distancoval. Její výuku převzali odborní učitelé Josef Tvrdoň a Alois Šebestík. Úroveň Ambrosem započaté umělecké tradice nejlépe dokazuje účast gymnaziálních pěveckých sborů vedených Aloisem Šebestíkem na krajské, a poté celostátní soutěži ansámblů československých středních škol konané 26. června až 1. července 1947 v Praze, kde v kategorii pěveckých sborů žabovřeští gymnazisté zvítězili. ${ }^{26}$ Vedle zaměstnání středoškolského profesora naplňovalo Ambrosovu pedagogickou činnost vzdělávání dospělých (respektive všech dobrovolně zúčastněných), podle dobového usu označované jako lidová výchova, kterou realizoval formou veřejných přednášek a rozhlasových relací. V Olomouci převážně o hudební problematice přednášel např̀. v Lidové škole, pěvecko-hudebním spolku Žerotín, Ústavu hraběte Pöttinga, Dobrovského vyšší lidové škole, Klubu sólistů českého divadla, Národní jednotě nebo ve Volném sdružení přátel moderní hudby. Z brněnských institucí spolupracoval s Klubem

20 Viz např. WAIC, František. Středoškolské akademie (koncerty). Věstnik československých profesorů, roč. XXXIV, č. 16-17, s. 253-254.

21 ROZSYPAL, J. Na rozloučenou s profesorem E. Ambrosem. Pozor, roč. XLII, č. 175, 28. 6. 1935, s. 3.

22 Archiv města Brna, fond M 86 Gymnázium Dr. Vladimíra Helferta v Brně-Žabovřeskách 1937-1953, osobní spis Emanuela Ambrose, inv. č. 71.

23 AMBROS, Emanuel. Sjezd hudebních pedagogů v Litomyšli. Slovo národa, roč. I, č. 97, 1. 9. 1945 , s. 3.

24 Viz korespondence Emanuela Ambrose Gustavu Pivoňkovi v soukromém vlastnictví pedagoga Pražské konzervatoře Jiřího Holeni.

25 Do roku 1951 výpomocně působil v hudebním oddělení Univerzitní knihovny.

26 Archiv města Brna, fond M 86 Gymnázium Dr. Vladimíra Helferta v Brně-Žabovřeskách 1937-1953, poradní protokoly. 
moravských skladatelo̊, v rámci tzv. Hudební Budče s Filharmonickým spolkem Beseda Brněnská a Komenského vyšší lidovou školou. Pravidelné edukativní pořady pro rozhlasové posluchače připravoval ze studia v Moravské Ostravě od roku 1931. ${ }^{27}$ Prokazatelně od května roku 1946 reflektoval hudební život pro brněnský Radiojournal. Navázal tak na předválečné Týdenní aktuality (s variantou názvu Kulturní přehled) svého přítele Graciana Černušáka (1882-1961). ${ }^{28}$

\section{Publikační činnost}

Počátky Ambrosovy kariéry hudebního kritika a zpravodaje zůstávají spjaty s prostějovským periodikem Hlasy z Hané, do něhož podle vlastních vzpomínek poprvé přispěl svými referáty o Trnkově divadelní společnosti někdy okolo roku 1904. ${ }^{29}$ Výraznější spolupráci navázal s olomouckými novinami Pozor a Československým denikem. Bádání ve jmenovaných seriálech odhaluje, že Ambros - podepisující své články šifrou Abs - za svého patnáctiletého působení v Olomouci zachytil podstatnou část meziválečného hudebního dění města. K tomu čtenáře kulturní rubriky informoval o významných uměleckých událostech konaných mimo region, recenzoval hudební příručky, přehlížel čísla některých aktuálně vydávaných tuzemských i zahraničních odborných časopisů, v neposlední řadě pak připomínal životní milníky skladatelů a interpretů. Informativní přehledy o hudbě v Olomouci resumující významné podniky podával Emanuel Ambros i do odborných časopisů jako např. Listů Hudebni Matice (Tempa) nebo Hudebnich rozhledů. Od konce roku 1926 začal pravidelně dopisovat také do Lidových novin.

Podobně intenzivně pokračoval i po přesídlení do Brna roku 1935. Nově se stal dopisovatelem Národních listů, týdeníku Zvon, v období válečných hrůz pak přispíval do večerníku Moravských novin. Žurnalistiky se stejně jako pedagogické kariéry vzdal koncem září 1949, kdy rozvázal spolupráci s redakcí Nové politiky. ${ }^{30}$ Za důležitou osobnost brněnské hudební kritiky uplatňující se vedle Graciana Černušáka, Jana Racka nebo Bohumíra Štědroně považoval Ambrose např. Rudolf Pečman ${ }^{31}$ či pamětnice kulturního profilu poválečného Brna Eva Šlapanská32.

27 jr. Cyklus hudebních relací prof. Em. Ambrose a prof. M. Zapletalové v mor.-ostravském radiu. Pozor, roč. XXXIX, č. 127, 2. 6. 1932, s. 4.

28 Vyplývá to z dopisu Gustavu Pivoňkovi ze dne 6. května 1946.

29 AMBROS, Emanuel. Hudební umění. Hlasy z Hané, roč. L, č. 25, 24. 6. 1932, s. 18.

30 O posledních měsících působení v periodiku mezitím přejmenovaného na Nová politika se dozvídáme z Ambrosova dopisu Otakaru Šourkovi: „Do Nové politiky /bývalé Slovo národa/ ještě referuji, ovšem jak tam budu nyni dlouho, je otázkou času. Byly těžké nápory proti mé osobě, většinou ideologické, nemajici s muzikou ničeho společného. Redakce si ovšem, nechci býti vychloubačný!, mé práce váži, dělám, co je v mých skromných silách a myslím, dèlám to spravedlivě a odborně. Snad tyto okolnosti drži nade mnou ochrannou ruku. Ale dnes? Je možné vše! "Viz České muzeum hudby. Muzeum Antonína Dvořáka: korespondence Emanuela Ambrose s Otakarem Šourkem, dopis z 25. srpna 1949, sign. S 274/G 30.

31 Viz PEČMAN, Rudolf. Jan Racek. Vědec a člověk. Brno: Opus musicum, 2010, s. 213.

32 Viz ŠLAPANSKÁ, Eva. Jak jsem je znala. Vzpominky na významné osobnosti kulturního života spjaté s Brnem. Brno: SVAN, 2001, s. 98. 
Samostatně publikovaných studií a spisů Ambrosova autorství vzniklo minimum. V době olomouckého pobytu se jeho ústřední zájem obracel zvláště k opernímu provozu místního divadla, a proto se ve výročních zprávách Družstva českého divadla v Olomouci objevovaly Ambrosovy roční bilance činnosti. Z nich pak Emanuel Ambros mohl těžit při tvorbě hesla o ústřední středomoravské kulturní instituci v Pazdírkově hudebním slovniku naučném nebo ve studii Dvacet let české opery v Olomouci (1920-1940) ${ }^{33}$.

Mimo historiografii olomouckého divadla se na konci dvacátých let zajímal o život a dílo Leoše Janáčka, se kterým se osobně znal. ${ }^{34} \mathrm{~V}$ ročence již zmiňovaného Družstva českého divadla v Olomouci uveřejnil pojednání Janáček - dramatik. ${ }^{55}$ Profil hukvaldského rodáka Ambros doplnil řadou „dosud málo známých nebo vůbec neznámých“ životopisných údajů ve studii pro časopis Hudba a škola. Zde poukázal na matriční zápisy rekonstruující genealogii rodu a publikoval výpověd' Arnošta Janáčka o tom, jak se jeho bratranec Leoš stal hudebníkem. ${ }^{36}$ Dále zveřejnil Janáčkův nedatovaný dopis, ve kterém mistr udílel pokyny k provedení svých Valašských tancư.$^{37}$ Ambros zároveň aktivně podporoval bádání předních janáčkologů Bohumíra Štědroně a Jana Racka. ${ }^{38}$

Ze čtyřicátých let 20. století jsou známy Ambrosovy ambice uceleně pojednat o Pavlu Kř́ižkovském ${ }^{39}$ nebo pro kandidáty státních zkoušek ze zpěvu na středních školách vytvořit př́ručku estetiky. ${ }^{40}$ Tiskem vydaná zůstala pouze jeho monografie Bedřich Smetana. S obsahy všech mistrových oper (1944), vycházející v edici nazvané Malé monografie o velkých zjevech brněnského nakladatelství Průboj. Kdybychom Ambrosovu publikaci porovnali s historicky mladšími smetanovskými biografiemi, nutně by popularizačním zpracováním rezonovala s prací Václava Holzknechta ${ }^{41}$.

33 AMBROS, Emanuel. Dvacet let české opery v Olomouci (1920-1940). In Vlastivěda střední a severní Moravy. Díl II. Středni a severni Morava v minulosti. Část prvá. Studie z kulturních dějin středni a severni Moravy. Černý, Norbert (ed.). Přerov, 1942, s. 536-550. Poslední tři roky činnosti olomoucké opery (1937-1940) dokončil Jaroslav Čičatka.

34 Podle vlastních slov prožil Emanuel Ambros s Leošem Janáčkem „mnohou chvíli, na kterou člověk nikdy nezapomene“ za svého působení na reálném gymnáziu v Kyjově, kde vyučoval v letech 1910-1913. Viz MZM ODH: Korespondence Vladimíra Helferta s Emanuelem Ambrosem, dopis z 25. listopadu 1937, sign. A 24, inv. č. 48. Několik Ambrosových dopisů osobní povahy adresovaných Janáčkovi uchovává MZM ODH.

35 AMBROS, Emanuel. Janáček - dramatik. In Výroční zpráva Družstva českého divadla v Olomouci za dobu od 1. července 1927 do 30. června 1928. Olomouc, 1928, s. 5-11.

36 AMBROS, Emanuel. K profilu života mistra Leoše Janáčka. Hudba a škola, roč. I, č. 9-10, s. 143-144.

37 AMBROS, Emanuel. Z korespondence Leoše Janáčka. Tempo. Listy hudebni matice, roč. IX, č. 1, s. 24-26.

38 Např. v dopisnici z října 1953 Ambros informoval Jana Racka, že pro něj má přichystány bliže nespecifikované „Janáčkovy památky“. Viz MZM ODH: Korespondence Jana Racka s Emanuelem Ambrosem, dopisnice ze 6. ř́jna 1953, sign. G 980, inv. č. 72.921.

39 Viz České muzeum hudby. Muzeum Antonína Dvořáka: Korespondence Emanuela Ambrose s Otakarem Šourkem, dopisnice ze 14. prosince 1946, sign. S 274/G 27.

40 Viz FRIC, Ota. Ambros Emanuel. In Fric, Ota (ed.). Hudba na Kroměřižsku a Zdounecku. Kroměříž, 1941, s. 19.

41 HOLZKNECHT, Václav. Bedřich Smetana. Život a dilo. Praha: Panton, 1979. 


\section{Tvůrčí podněty a organizační iniciativa}

Zejména prvorepublikoví Olomoučané mohli Emanuela Ambrose považovat za vlivného agitátora hudebního života, těžícího ze zkušeností s kulturním provozem dř́ivějších působišt' (Praha, Vídeň ${ }^{42}$, Brno). Spoluprací s místními institucemi měl jako renomovaný odborník napomoci k profesionalizaci umělecké úrovně. Chyběla-li vhodná platforma $\mathrm{k}$ realizaci některých jeho vizí, sám zaujal čelné funkce v nově vytvářených organizacích, jak se stalo v př́padě olomoucké frakce Sboru pro oslavy Smetanovy nebo ve Volném sdružení přátel moderní hudby v Olomouci.

V Brně se Ambros angažoval v pedagogickém odboru Filharmonického spolku Beseda Brněnská a výboru Klubu moravských skladatelů. Roku 1936 inicioval vznik a jako předseda působil v sekci pro zpěv při brněnském odboru Ústředního spolku československých profesorů. Poslední léta života se navzdory zdravotním obtíźím věnoval pořádání koncertů pro Náboženskou společnost unitářu československých.

\subsection{Olomouc}

Celonárodní oslavy stého výročí od narození Bedřicha Smetany měly být naplněny spoluúčastí co možná největšího počtu obcí, které by přímo úměrně svým možnostem přichystaly na jubilejní rok 1924 vlastní program realizovaný formou koncertů, přednášek, stavbou pomníkủ či pamětních desek, peněžitých sbírek apod. Na Moravě se o propagaci Smetanova odkazu zasadil především Vladimír Helfert, který podnítil vznik Sboru pro oslavu 100. narozenin Bedřicha Smetany na Moravě..$^{43}$

Plány brněnského ústředí pro Olomouc rozpracoval Emanuel Ambros, který se stal předsedou Sboru pro oslavy Smetanovy a vedl jeho přednáškovou a popularizační sekci. ${ }^{44}$ Činnost olomouckého sdružení se dála dvěma směry. Jedním byla organizace souborného provedení Smetanova díla a druhým cílem se stalo postavení v Olomouci prvního pomníku litomyšlskému rodákovi.

V období od 31. ledna do 18. května 1924 zazněly v Olomouci až na některé skladby z mládí a fragment opery Viola všechny Smetanovy kompozice. Na jejich nastudování se mimo jiných podílely přední olomoucké instituce, jakož i Česká filharmonie a České kvarteto. ${ }^{45}$ Smetanovy oslavy měly rovněž vliv na dramaturgii německých operních scén, které předtím uvádění děl českých skladatelů tendenčně odmítaly. Tak hostující německý ansámbl sehrál v olomouckém divadle dne 14. března 1924 Smetanovu veselohru Hubička, věstící „proni červánky dalšiho společného soužiti na poli hudebni kultury, která je

42 Kvůli vleklým zdravotním komplikacím byl koncem roku 1917 přeložen z uherské fronty k domobraneckému c. k. leteckému oddílu ve Vídni. Podle vlastnoručně psaných memoárů hojně navštěvoval divadelní představení, z nichž ponejvíce preferoval opery Richarda Wagnera a Richarda Strausse. Viz SOkA Prostějov, fond Emanuel Ambros, Rodinná kronika 1914-1919, s. 5.

43 VYSLOUŽIL, Jiří. Vladimír Helfert. In Vladimír Helfert. Pokrokový vědec a clověk. Brno, 1975, s. 9.

44 Jubilejní oslavy Smetanovy v Olomouci. Selské listy, roč. XL, č. 38, 16. 9. 1922, s. 4.

45 AMBROS, Emanuel. Smetanovy oslavy v Olomouci. Hudebni rozhledy, roč. I, č. 1-2, 10. 10. 1924, s. 22-23. 
nejpevnějším pojítkem obou národnosti a před kterou ustoupiti musí každý disharmonický tón národnostnich rozdili $[\ldots] . . " 46$

Odhalení pomníku oslavovaného mistra situovaného na hlavní aleji Smetanových sadů proběhlo oproti původnímu záměru s ročním zpožděním. Realizace díla akademického sochaře Rudolfa Březy a jeho spolupracovníka Josefa Štěpánka souviselo jednak s projevem obdivu ke Smetanově géniu, jednak mělo manifestovat silné vlastenecké cítění, kterého byl Smetanův tvưrčí odkaz všeobecným vzorem. Slavnosti spojené s předáním pomníku do městské správy probíhaly 2. a 3. května $1925 .{ }^{47}$

Jméno Emanuela Ambrose zůstává v oblasti organizační iniciativy nejvýrazněji spjato s Volným sdružením přátel moderní hudby v Olomouci, ustaveným dne 12. záři 1927 v olomoucké kavárně Grand na Masarykově náměstí. V prvním roce činnosti zde působili jako předseda Karel Fuhrich (1873-1953), ${ }^{48}$ jednatel Emanuel Ambros, dále Richard Kopa, Gustav Pivoňka, kapitán Antonín Malík, primář Trapl, J. Bartošová, vikář František Večeřa, J. Drábek, Karel Kořínek a nakladatel Romuald Promberger. ${ }^{49}$ Primárním cílem těchto dobrovolně se sdružujících zájemcư ${ }^{50}$ se stala interpretace a popularizace písňové a komorní tvorby soudobých autorů.

Naplnění programu sdružení sledujícího vzory pražského Spolku pro moderní hudbu (1920) a brněnského Klubu moravských skladatelů (1922) lze během deset let trvající existence spatřovat v několika směrech. Hlavní těžiště činnosti představovalo organizování koncertů, na nichž vystupovali profesionálně školení umělci. Jednotlivé produkce nelimitovala jednotící dramaturgická koncepce. Volba konkrétního díla závisela v mnoha případech na interpretově nabídce, a tak se okruh tvorby rozšiřoval z českých i na zahraniční autory, stejně tak i pravidlo „modernosti“ nebylo striktně dodržováno. ${ }^{51}$

Důležitého místa se na programech jednotlivých hudebních večerů dostávalo přednáškám, prezentující vybrané skladatelské osobnosti, popřípadě zabývající se specifiky kompozičního stylu konkrétních kompozic. Obsah některých přednášek konvenoval s aktuálním děním města, kdy byli posluchači před divadelními premiérami prostřednictvím šéfa opery, vybraných interpretů nebo režiséra informování o chystané inscenaci. Ze zahraničních témat nejvíce prostoru zaujala pojednání o ruském hudebním umění.

46 Abs (Emanuel Ambros). Z olomoucké opery. Smetanova Hubička na německé scéně. Československý deník, roč. VI, č. $65,16.3 .1924$, s. 4.

47 AMBROS, Emanuel. Smetanův pomník v Olomouci. Smetana, roč. XV, č. 4-5, 14. 8. 1925, s. 78-79.

48 Civilním zaměstnáním lékárník Karel Fuhrich byl štědrým podporovatelem umění. Jeho jméno zůstává spojeno s olomouckými uměleckými organizacemi, jako např. s Družstvem českého divadla, Volným sdružením přátel nebo Spolkem pro komorní hudbu. Více viz FUHRICH, Karel. Vzpominky starého lékárnika. Olomouc, 1948.

49 MZM ODH, jednatelská kniha Volného sdružení přátel moderní hudby v Olomouci, sign. 46, inv. č. 11.347, s. $1-3$.

50 Volné sdružení přátel moderní hudby v Olomouci fungovalo bez pevné organizační základny - bez stanov, výborových schůzí a oficiálně přihlášených členů, tudíž bez pravidelných členských příspěvků.

51 Právě nesoustavnost a různorodost zařazovaných děl jako projev režijního nedostatku zapříčinily podle Roberta Smetany neschopnost Volného sdružení přátel moderní hudby v Olomouci vytvořit trvalou platformu - hudební společnost - stabilizující vztah publika k soudobé hudbě. Viz SMETANA, Robert. O nový český hudebni život. Olomouc: Spolek pro komorní hudbu, 1947, s. 65. 
Dějiny tvoři "ti malí" aneb Život a dílo Emanuela Ambrose

\begin{tabular}{|c|c|c|c|c|}
\hline \multicolumn{5}{|c|}{ Produkce Volného sdružení přátel moderní hudby v Olomouci } \\
\hline \multicolumn{5}{|c|}{ Sezóna $1927 / 1928$} \\
\hline $\begin{array}{l}\text { Název } \\
\text { události }\end{array}$ & Datum & $\begin{array}{l}\text { Místo } \\
\text { konání }\end{array}$ & Program & Účinkující \\
\hline \multirow{10}{*}{$\begin{array}{l}\text { Prvý } \\
\text { hudební } \\
\text { večer }\end{array}$} & \multirow{10}{*}{$\begin{array}{l}\text { 15. října } \\
1927\end{array}$} & \multirow{10}{*}{$\begin{array}{l}\text { Hudební } \\
\text { síň dívčího } \\
\text { gymnázia }\end{array}$} & Proslov & Emanuel Ambros \\
\hline & & & Leoš Janáček: Po zarostlém chodníčku & Gustav Pivoňka (klavír) \\
\hline & & & $\begin{array}{l}\text { Jaroslav Kvapil: Stará viola } \\
\text { Kdy duše zpívá }\end{array}$ & \multirow{2}{*}{$\begin{array}{l}\text { Marie Hloušková (zpěv) } \\
\text { Gustav Pivoňka (klavír) }\end{array}$} \\
\hline & & & Jan Kunc: Ze života č. 1, op. 10 & \\
\hline & & & Emil Axman: Morava zpívá & Richard Kopa (klavír) \\
\hline & & & Vilém Petrželka: Ztratil jsem & \multirow{3}{*}{$\begin{array}{l}\text { Marie Hloušková } \\
\text { Gustav Pivoňka }\end{array}$} \\
\hline & & & Osvald Chlubna: Fragment, op. 6 & \\
\hline & & & $\begin{array}{l}\text { Pavel Haas: Šest písní v lidovém tónu } \\
\text { č. } 2 \text { a 6, op. } 1\end{array}$ & \\
\hline & & & Leoš Janáček: V mlhách & Gustav Pivoňka \\
\hline & & & Doslov & Karel Fuhrich \\
\hline \multirow{5}{*}{$\begin{array}{l}\text { Druhý } \\
\text { hudební } \\
\text { večer }\end{array}$} & \multirow{5}{*}{$\begin{array}{l}\text { 14. lis- } \\
\text { topadu } \\
1927\end{array}$} & \multirow{5}{*}{$\begin{array}{l}\text { Hudební } \\
\text { síň dívčího } \\
\text { gymnázia }\end{array}$} & Jaroslav Novotný: Věčná svatba, op. 2 & $\begin{array}{c}\text { Eva Hadrabová-Nedbalo- } \\
\text { vá (zpěv) } \\
\text { Karel Nedbal (klavír) }\end{array}$ \\
\hline & & & Přednáška „Filosofie hudby Smetanovy" & Emanuel Ambros \\
\hline & & & $\begin{array}{l}\text { Vítězslav Novák: Melancholické písně } \\
\text { o lásce č. } 1 \text { a 2, op. } 38\end{array}$ & \multirow{2}{*}{$\begin{array}{c}\text { Eva Hadrabová-Nedba- } \\
\text { lová } \\
\text { Karel Nedbal }\end{array}$} \\
\hline & & & $\begin{array}{l}\text { Ladislav Vycpálek: Moravské balady č. } 2 \\
\text { a 5, op. } 12\end{array}$ & \\
\hline & & & Doslov & Karel Fuhrich \\
\hline \multirow{8}{*}{$\begin{array}{l}\text { Tretí ve- } \\
\text { čer poesie } \\
\text { a hudby } \\
\text { věnovaný } \\
\text { bratřím } \\
\text { Petru a Ja- } \\
\text { roslavu } \\
\text { Křičkovi }\end{array}$} & \multirow{8}{*}{$\begin{array}{l}\text { 12. pro- } \\
\text { since } \\
1927\end{array}$} & \multirow{8}{*}{$\begin{array}{l}\text { Důstojnic- } \\
\text { ké kasino }\end{array}$} & Přednáška "O básníku Petru Křičkovi" & Klement Králík \\
\hline & & & Recitace & F. Salzer \\
\hline & & & Proslov & Jaroslav Křička \\
\hline & & & $\begin{array}{l}\text { Jaroslav Křička: Památník ze staré ško- } \\
\text { ly, op. } 35\end{array}$ & $\begin{array}{l}\text { Lída Borovičková (zpěv) } \\
\text { Gustav Pivoňka (klavír) }\end{array}$ \\
\hline & & & $\begin{array}{l}\text { Jaroslav Křička: Veselé kousky č. } 1 \text { a 3, } \\
\text { op. } 13\end{array}$ & Anděla Sékorová (klavír) \\
\hline & & & Jaroslav Křička: Severní noci, op. 14 & $\begin{array}{l}\text { Sláva Mazáková (zpěv) } \\
\text { Jaroslav Křička (klavír) }\end{array}$ \\
\hline & & & $\begin{array}{l}\text { Jaroslav Křička: Veselé kousky č. } 2 \text { a 7, } \\
\text { op. } 13\end{array}$ & Soňa Sékorová (klavír) \\
\hline & & & Jaroslav Křička: Tři bajky, op. 21 & $\begin{array}{l}\text { Lída Borovičková } \\
\text { Jaroslav Křička }\end{array}$ \\
\hline \multirow[b]{2}{*}{$\begin{array}{l}\text { Čtvrtý } \\
\text { večer }\end{array}$} & \multirow[b]{2}{*}{$\begin{array}{l}\text { 3. ledna } \\
1928\end{array}$} & \multirow[b]{2}{*}{$\begin{array}{l}\text { Hudební } \\
\text { síň dívčího } \\
\text { gymnázia }\end{array}$} & Přednáška „Rozbor Straussovy Elektry” & Emanuel Ambros \\
\hline & & & Hudební ukázky z opery & $\begin{array}{c}\text { Eva Hadrabová-Nedbalo- } \\
\text { vá (zpěv) } \\
\text { Alba Sehnalová (zpěv) } \\
\text { Jaroslav Budík (klavír) }\end{array}$ \\
\hline \multirow{4}{*}{$\begin{array}{c}\text { V. večer } \\
\text { komorní } \\
\text { hudby } \\
\text { Moravské- } \\
\text { ho kvarte- } \\
\text { ta z Brna }\end{array}$} & \multirow{4}{*}{$\begin{array}{l}\text { 30. ledna } \\
1928\end{array}$} & \multirow{4}{*}{$\begin{array}{l}\text { Důstojnic- } \\
\text { ké kasino }\end{array}$} & Proslov & Gustav Pivoňka \\
\hline & & & $\begin{array}{l}\text { Břetislav Bakala: Smyčcový kvartet } \\
\text { [C dur] }\end{array}$ & \multirow{3}{*}{$\begin{array}{c}\text { Moravské kvarteto: } \\
\text { František Kudláček } \\
\text { (housle) } \\
\text { Josef Jedlička (housle) } \\
\text { Josef Trkan (viola) } \\
\text { Josef Křenek (violon- } \\
\text { cello) }\end{array}$} \\
\hline & & & $\begin{array}{l}\text { Jaroslav Kvapil: 2. smyčcový kvartet } \\
\text { e moll }\end{array}$ & \\
\hline & & & $\begin{array}{l}\text { Karol Szymanowski: Smyčcový kvartet } \\
\text { C dur, op. } 37\end{array}$ & \\
\hline
\end{tabular}




\begin{tabular}{|c|c|c|c|c|}
\hline \multicolumn{5}{|c|}{ Produkce Volného sdružení přátel moderní hudby v Olomouci } \\
\hline \multicolumn{5}{|c|}{ Sezóna 1927/1928 } \\
\hline $\begin{array}{l}\text { Název } \\
\text { události }\end{array}$ & Datum & $\begin{array}{l}\text { Místo } \\
\text { konání }\end{array}$ & Program & Účinkující \\
\hline \multirow{7}{*}{$\begin{array}{l}\text { VI. pís- } \\
\text { ňový } \\
\text { a klavírní } \\
\text { večer }\end{array}$} & \multirow{7}{*}{$\begin{array}{l}\text { 27. února } \\
1928\end{array}$} & \multirow{7}{*}{$\begin{array}{l}\text { Důstojnic- } \\
\text { ké kasino }\end{array}$} & Proslov a rozbor uváděných skladeb & Emanuel Ambros \\
\hline & & & $\begin{array}{l}\text { Vítězslav Novák: Údolí Nového králov- } \\
\text { ství, op. } 31\end{array}$ & $\begin{array}{c}\text { Stanislav Tauber (zpěv) } \\
\text { Jaroslav Kvapil (klavír) }\end{array}$ \\
\hline & & & Maurice Ravel: Sonatina fis moll & Jaroslav Kvapil \\
\hline & & & $\begin{array}{l}\text { Karel Boleslav Jirák: Lyrické intermezzo, } \\
\text { op. } 4\end{array}$ & $\begin{array}{l}\text { Stanislav Tauber } \\
\text { Jaroslav Kvapil }\end{array}$ \\
\hline & & & $\begin{array}{l}\text { Jaroslav Kvapil: Variace pro klavír } \\
\text { na vlastní téma }\end{array}$ & Jaroslav Kvapil \\
\hline & & & Otakar Ostrčil: Cizí host, op. 16 & \multirow{2}{*}{$\begin{array}{l}\text { Stanislav Tauber } \\
\text { Jaroslav Kvapil }\end{array}$} \\
\hline & & & Richard Strauss: výběr písní & \\
\hline \multirow{3}{*}{$\begin{array}{l}\text { VII. před- } \\
\text { náškový } \\
\text { a písňový } \\
\text { večer }\end{array}$} & \multirow{3}{*}{$\begin{array}{l}\text { 14. břez- } \\
\text { na } 1928\end{array}$} & \multirow{3}{*}{$\begin{array}{l}\text { Hudební } \\
\text { síň dívčího } \\
\text { gymnázia }\end{array}$} & $\begin{array}{l}\text { Přednáška „Richard Wagner v letech } \\
\text { vzniku Tristana” }\end{array}$ & Karel Kořínek \\
\hline & & & $\begin{array}{l}\text { Čtení deníkových záznamů R. Wagnera } \\
\text { z let 1857-1858 }\end{array}$ & Otto F. Babler \\
\hline & & & $\begin{array}{l}\text { Richard Wagner: písně na texty Matildy } \\
\text { Wesendonkové }\end{array}$ & $\begin{array}{l}\text { Olga Vlková-Špillingová } \\
\text { (zpěv) } \\
\text { Gustav Pivoňka (klavír) }\end{array}$ \\
\hline \multirow{4}{*}{$\begin{array}{c}\text { VIII. večer } \\
\text { hous- } \\
\text { lových } \\
\text { sonát }\end{array}$} & \multirow{4}{*}{$\begin{array}{l}\text { 17. dubna } \\
1928\end{array}$} & \multirow{4}{*}{$\begin{array}{l}\text { Důstojnic- } \\
\text { ké kasino }\end{array}$} & Proslov a rozbor uváděných skladeb & Emanuel Ambros \\
\hline & & & Paul Hindemith: Sonáta č. 2, op. 11 & \multirow{3}{*}{$\begin{array}{l}\text { Josef Holub (housle) } \\
\text { Bohumil Holub (klavír) }\end{array}$} \\
\hline & & & $\begin{array}{l}\text { Claude Debussy: Sonáta pro housle } \\
\text { a klavír [g moll, op. 140] } \\
\end{array}$ & \\
\hline & & & $\begin{array}{l}\text { Ildebrando Pizzetti: Sonáta pro housle } \\
\text { a klavír }\end{array}$ & \\
\hline
\end{tabular}

Tab. 1 Produkce pořádané Volným sdružením přátel moderní hudby v Olomouci v první sezóně existence. Zdroj: MZM ODH, jednatelská kniha Volného sdružení prátel moderní hudby v Olomouci, sign. 46, inv. č. 11.347.

Ambrosovo ústřední postavení související s organizací většiny koncertů Volného sdružení přátel moderní hudby v Olomouci prověřil jeho odchod do Brna na konci sezóny 1934/1935 (odpovídalo trvání školního roku). Jednatelskou funkci po něm převzal Bohuslav Ilek, který se stal svědkem postupné stagnace trvající dva roky. Na aktivity sdružení navázal v prosinci 1937 ustavený Spolek pro komorní hudbu, do jehož čela se postavil Karel Fuhrich a jako první jednatel figuroval Robert Smetana (1904-1988).

Důležitost významu Volného sdružení přátel moderní hudby v Olomouci zůstává plně srovnatelná např. s brněnským Klubem moravských skladatelů. ${ }^{52}$ Přehlédnutí programů produkcí obou organizacín ${ }^{33}$ zjistíme patrnou inklinaci olomouckého sdružení publikum na soudobou hudbu připravovat nejen poslechem, ale také průvodním slovem či samostatnou přednáškou. Exkluzivitu koncertům Klubu moravských skladatelů dodával samotný

52 Srov. -k (Gracian Černušák). Šedesát let Emanuela Ambrose. Svobodné noviny, roč. I, č. 106, 26. 9. 1945, s. 3. 53 Koncertní činnost Klubu moravských skladatelů v letech 1922-1948 na základě pramenného materiálu a primární literatury viz VOHNOUTOVÁ EL ROUMHAINOVÁ, Suzanne: Počátky Klubu moravských skladateli̊ (1919-1928). Brno 2013. Magisterská diplomová práce. Masarykova univerzita v Brně, filozofická fakulta, ústav hudební vědy, s. 110-191. 
výběr provozovaného repertoáru, zahrnující mnohé komorní kompozice v Brně působících autorů, které zde zaznívaly ve světových premiérách. Olomouci výrazné skladatelské osobnosti chyběly. Nicméně mnoho z uváděných děl na produkcích Volného sdružení provázel status olomoucké novinky. K interpretaci jednotlivých skladeb obě organizace zvaly profesionální umělce. Uznání Ambrosova př́ínosu pak potvrzuje fakt, že se po svém přemístění do Brna stal aktivním členem výboru Klubu moravských skladatelů.

\subsection{Brno}

V moravské metropoli Emanuel Ambros ve filigránské organizační práci úspěšně pokračoval. Někdy na začátku roku 1936 Ambros při brněnském odboru Ústředního spolku československých profesorů (ÚSČP) inicioval vznik sekce pro zpěv, kde přijal funkci předsedy, jednatelem byl zvolen Bohumír Štědroň. ${ }^{54}$ Centrální zájem ÚSČP tkvěl v řešení teoretických i praktických otázek týkajících se pedagogiky, didaktiky a organizace škol středoškolského typu s přesahy do veřejné sféry. V souladu s přijatými stanovami zahrnovala činnost stavovských a odborných sekcí mj. pořádání přednášek, exkurzí, divadelních a filmových představení, koncertů a dalších podniků, směřujících ke vzdělávání členstva i žactva. ${ }^{55}$

Ambrosem vedená sekce se na svých prvních schůzích mj. zabývala úrovní hudební výchovy na středních školách. O problematice pojednal také Emanuel Ambros, schvalující myšlenky Vladimíra Helferta ${ }^{56}$, když požadoval reformu hudební výchovy jako komplexního naukového předmětu, jehož obsah by měl vedle praktického zpěvu zahrnovat vzdělávání ve vybraných oblastech hudební teorie. ${ }^{57}$

Aktivitou se brněnská sekce pro zpěv vyrovnávala pražské odbočce vedené Ambrosovým přítelem Jaromírem Fialou (1892-1967). ${ }^{58}$ Do úplné stagnace zapříčiněné válečnými událostmi se např. dne 12. února 1938 podařilo v Brně-Králově Poli uspořádat „Pracovní den zpěvu“, na kterém dvěma stovkám shromážděných pedagogů prezentoval lektor kurzu Josef Masopust z Chrudimi téma příčiny a řešení úpadku zpěvu a některé praktické rady pro hlasový výcvik žáku․ ${ }^{59}$ Následujícího roku byl dokonce zorganizován kurz hudební výchovy, při kterém Emanuel Ambros vedl metodiku zpěvu. ${ }^{60}$

54 A. Sekce pro zpěv. Věstnik československých profesorů, roč. XLIII, č. 15, 30. 3. 1936, s. 251.

55 Nové stanovy ÚSČP (nabývající platnosti 1. září 1934) in Vlastivědné muzeum v Olomouci, fond František Waic, karton 33.

Organizační důsledky pro krajinské odbory a stavovské sekce ÚSČP plynoucí z přijetí nových stanov publikovány v př́loze Věstniku československých profesorů, roč. XLII, č. 2-3, 5. 10. 1934, s. 34-37.

56 Názory předních hudebních vědců dobrovolníkům, mezi nimiž nechyběl ani Emanuel Ambros, zprostředkoval první kurz pro profesory zpěvu na středních školách konaný v Brně od 9. do 21. července 1934. Jedním z iniciátorů setkání byl právě Vladimír Helfert, který představil své myšlenky o středoškolské hudební výchově, hudebních formách a jejich psychologických a estetických základech. Viz Abs (Emanuel Ambros). Kurs pro profesory zpěvu na středních školách. Moravský denik, roč. XXIX, č. 172, 25. 7. 1934, s. 4.

57 AMBROS, Emanuel. V práci pro hudební nauku na školách středních. Index, roč. VIII, č. 3, s. 29-30.

58 Ambrosem odeslanou korespondenci Jaromíru Fialovi spravuje MZM ODH pod signaturou G 7.445.

59 Viz VOŠLAJEROVÁ, Marie. Sekce zpěvu a hudební výchovy při brněnském krajinském odboru Ústředního spolku čsl. profesorů. Věstnik československých profesorů, roč. XLV, č. 14, 1. 3. 1938, s. 254.

60 Viz dopis Gustavu Pivoňkovi ze dne 13. ř́jna 1939 v majetku Jiřího Holeni. 
Z Ambrosovy korespondence s brněnským skladatelem, hudebním kritikem a pedagogem Janem Kuncem (1883-1976) se dozvídáme o organizaci koncertů pro Náboženskou společnost unitářu československých. Unitáři při pravidelných shromážděních dbali na hledání osobní duchovní cesty skrze četbu literatury, poezie, náboženských textů různých kultur a provozování hudebního umění. Vedle hudebních vložek při některých setkáních uspořádal Ambros dne 7. května 1954 v sále českobratrské církve evangelické samostatný koncertní večer věnovaný Kuncovým skladbám. Blíže neurčené autorovy písně zpívala Běla Syková-Dejmková (1923-?), komorní soubor tvořený profesory brněnské konzervatoře interpretoval trio $f$ moll, op. 3 a Ambrosova snacha Dagmar Ambrosová přednesla Kuncovy České tance, op. $34 .{ }^{61}$

\section{Slovo závěrem - Emanuel Ambros včera a dnes}

Emanuel Ambros podnětně ovlivnil umělecký rozvoj meziválečné Olomouce. Z pozice středoškolského pedagoga a renomovaného řečníka edukoval nejširší vrstvy obyvatel. Se studentskými pěveckými sbory pořádal hodnotné veřejné produkce. Prostřednictvím rozsáhlé publikační činnosti nejen vychovával, ale také kritickým hodnocením proklamoval požadavky a nároky na zkvalitnění kulturní úrovně. V neposlední řadě pak sám jako interpret a organizátor do tohoto dění přispíval. Opus magnum Ambrosovy iniciativy představovalo Volné sdružení přátel moderní hudby, které se pořádáním přednášek a koncertů věnovaných soudobé komorní a písňové tvorbě vyrovnávalo aktivitám brněnského Klubu moravských skladatelů. Ambrosův význam pro Olomouc si plně uvědomovali již jeho současníci, kteří jej označovali za „osu a ducha veškerého hudebního dění města."62

Profesionalizace kulturního života, které se Emanuel Ambros v „provinční“ Olomouci organicky účastnil, byla na dalším působišti v Brně podchycena prací akademicky školených odborníků. Gracian Černušák, Vladimír Helfert, Jan Racek, Bohumír Štědroň a mnozí další do moravské metropole Ambrose přijímali jako respektovaného pedagoga a hudebního kritika. Nicméně právě přítomnost profesionálních hudebníků, většinou jeho známých, nedovolila intenzivnější rozlet činností, jak při odchodu z Olomouce roku 1935 plánoval. Další záměry pak utlumilo vyhlášení Protektorátu Čechy a Morava. Nová politická situace po válce představovala pro demokrata Ambrose spíše zklamání, které umocnilo nejmenování do funkce odborného inspektora hudební výchovy. Od začátku školního roku 1946/1947 demonstrativně zanechal výuky předmětů spojených s hudbou. Z veřejné sféry se pak definitivně odmlčel při odchodu do penze, kdy se současně vzdal i hudebně kritické činnosti.

Osobnostní profil Emanuela Ambrose nejlépe dokládají články publikované při příležitosti jeho jubileí. Jaromír Michal šedesátníka Ambrose charakterizoval jako neobyčejně

61 MZM ODH, korespondence Janu Kuncovi, sign. G 703.

62 Prof. Em. Ambros odchází z Olomouce. Moravský denik, roč. XXX, č. 135, 9. 6. 1935, s. 3. 
aktivního člověka, vzdalujícího se nečinnosti a zahálce, jemuž hudba byla životní láskou. Jan Racek psal o příznačné veselosti, nervózní pohyblivosti, čilosti a pracovitosti. Gracian Černušák viděl největší Ambrosovu přednost ve snaze vzbuzovat zájem o hudební umění v nejširších lidových vrstvách. ${ }^{63} \mathrm{Z}$ vlastního poznávání Ambrosova pozůstalostního materiálu můžeme dále doplnit, že představoval typ vzdělance $s$ neobyčejně širokým kulturním rozhledem. V duchu skromnosti obdivoval práci „významnějších“ současníků, jejichž učení přístupnou formou dále zprostředkovával.

Pro dnešní generace zůstává nezměrná životní práce Emanuela Ambrose zapomenuta. Z jeho díla se veřejnosti zachoval tiskem vydaný cyklus písní Nálady duše a monografie o Bedřichu Smetanovi. Většího významu nabývá odkaz vytvořený Ambrosovou hudebně kritickou činností, kdy se stal přímým svědkem důležitých kulturních událostí Moravy. $\mathrm{S}$ jeho hudebně historiografickými studiemi by měl přijít do styku každý badatel, fundovaně se zajímající o počátky české operní scény v Olomouci. V neposlední řadě nám Ambrosovy aktivity mohou být příkladem úsilí, prostřednictvím něhož se jedinec bez vidiny zisku či slávy snaží zkvalitnit život ostatním.

\section{Bibliography}

AMBROS, Emanuel. Bedřich Smetana. S obsahy všech mistrových oper. Brno: Průboj, 1944.

AMBROS, Emanuel. Dvacet let české opery v Olomouci (1920-1940). In Vlastivěda středni a severni Moravy. Díl II. Středni a severni Morava v minulosti. Část prvá. Studie z kulturnich dějin středni a severni Moravy. Černý, Norbert (ed.). Přerov, 1942, s. 536-550.

AMBROS, Emanuel. Janáček - dramatik. In Výročni zpráva Družstva českého divadla v Olomouci za dobu od 1. července 1927 do 30. června 1928. Olomouc, 1928, s. 5-11.

AMBROS, Emanuel. Ǩeditel Josef Klvaňa a hudba. In Čtyřicet let československého státního reálného gymnasia Josefa Klvani v Kyjově 1898-1938. Kolaja, Maxmilián (ed.). Kyjov, 1938, s. 175.

BALÓDY, Milan: Život a dílo Emanuela Ambrose (1885-1955). Olomouc 2017. Univerzita Palackého v Olomouci, filozofická fakulta, katedra muzikologie.

FISCHER, Richard (ed.). Olomoucký památnik 1848-1918. Olomouc, 1938.

FRIC, Ota. Ambros Emanuel. In Fric, Ota (ed.). Hudba na Kroměřižsku a Zdounecku. Kroměříž, 1941.

FUHRICH, Karel. Vzpominky starého lékárnika. Olomouc, 1948.

GREGOR, Vladimír. Vladimír Ambros. Prostějov: Okresní vlastivědné muzeum, 1969.

PEČMAN, Rudolf. Jan Racek. Vědec a člověk. Brno: Opus musicum, 2010, s. 213.

VOHNOUTOVÁ EL ROUMHAINOVÁ, Suzanne: Počátky Klubu moravských skladatelů (1919-1928).

Brno 2013. Magisterská diplomová práce. Masarykova univerzita v Brně, filozofická fakulta, ústav hudební vědy.

VYSLOUŽIL, Jiří. Vladimír Helfert. In Vladimír Helfert. Pokrokový vědec a člověk. Brno, 1975, s. 9. SILNÁ, Ingrid. Ezechiel Ambros. Olomouc: Univerzita Palackého v Olomouci, 2011.

SMETANA, Robert. O nový český hudebni život. Olomouc: Spolek pro komorní hudbu, 1947.

63 MICHAL, Jaromír. Prof. Emanuel Ambros šedesátníkem. Slovo národa, roč. I, č. 118, 26. 9. 1945, s. 3.

RACEK, Jan. Emanuelu Ambrosovi k šedesátce. Rovnost, roč. LXI, č. 118, 26. 9. 1945, s. 3.

-k (Černušák, Gracian). Šedesát let Emanuela Ambrose. Svobodné noviny, roč. I, č. 106, 26. 9. 1945 , s. 3. 
ŠLAPANSKÁ, Eva. Jak jsem je znala. Vzpominky na významné osobnosti kulturního života spjaté s Brnem. Brno: SVAN, 2001.

ŠTĚDROŇ, Bohumír. Ambros Emanuel. In Československý hudebni slovnik osob a instituci. Černušák, Gracian - Štědroň, Bohumír - Nováček, Zdenko (eds.). Svazek první. Praha: Státní hudební vydavatelství, 1963, s. 25-26. 